\title{
BIOSORPTION OF COPPER, ZINC AND NICKEL FROM MULTI-ION SOLUTIONS
}

\author{
JANA KADUKOVÁ, HEDVIGA HORVÁTHOVÁ \\ Technical University in Košice, Faculty of Metallurgy, Department of Material \\ Science, Letná 9, Košice, 040 00, Slovak Republic (jana.kadukova@tuke.sk)
}

\begin{abstract}
The biosorption of $\mathrm{Cu}(\mathrm{II}), \mathrm{Zn}(\mathrm{II})$ and $\mathrm{Ni}(\mathrm{II})$ by microscopic green algae Chlorella kessleri was investigated using batch experiments. Biosorption studies with single and multi ion solutions were carried out to study the effect of several ions on the biosorption of selected metal. The influence of zinc and nickel on copper biosorption, copper and nickel on zinc biosorption and zinc and copper on nickel biosorption were investigated. The Langmuir and Freundlich model were used to describe the adsorption equilibrium of studied metals on Chlorella kessleri biomass. Based on the experimental results it was found that the presence of copper increased the biosorption capacity of zinc from $48.6 \mathrm{mg} / \mathrm{g}$ to $96.8 \mathrm{mg} / \mathrm{g}$ and nickel from $29.3 \mathrm{mg} / \mathrm{g}$ to $62.7 \mathrm{mg} / \mathrm{g}$, respectively. However, the presence of nickel decreased the biosorption capacity of zinc from $48.6 \mathrm{mg} / \mathrm{g}$ to $31.7 \mathrm{mg} / \mathrm{g}$.
\end{abstract}

Key words: adsorption isotherms, biosorption, Chlorella kessleri, heavy metals, bioavailability

\section{Introduction}

Environmental pollution is a very serious problem in the present time. The main sources of heavy metals contamination in wastewater derived from electroplating, metal finishing and metallurgical industry. Metals like copper, zinc and nickel are present in almost all types of wastewaters. These metals are toxic even at low concentrations (KADUKOVÁ and VIRČÍKOVÁ, 2003). Several studies reported the biosorption of these metals from solution using different types of biosorbents. Filamentous fungus Rhizopus arrhizus have been used for effective biosorption of copper and nickel from single ion solutions (SAG and ARDA, 2000). Peanut shell biomass also showed good biosorption capacity for copper (ANNA and ROMAN, 2011). Phaseolus vulgaris immobilized in silica-gel had good biosorption capacity for nickel (AKAR and ZERRIN, 2009). Zinc can be effectively removed by activated sludge or by Penicillium simplicissimum biomass (CHUNPING and MIN, 2010). Bacterial strains Bacillus cereus and Pseudomonas sp. showed promising biosorption capacity for nickel and zinc (WEI - CHEN and CHIEH - CHEN, 2008). The major problem in wastewater treatment is that it usually contains more than one metal. The presence of several metals in solution may have a synergistic or conversely antagonistic effect on their biosorption, which depends on many factors, such as the quantity of metal ions competing for the same binding sites, the concentration of metal ions, the nature and concentration of biosorbent (WANG and YONG, 2005; HORVÁTHOVÁ, KADUKOVÁ, 2008; MAREŠOVÁ et al., 2011). Due to this fact it is very important to study the influence of several metals on their biosorption as well as to study the biosorption process itself. In terms of metal biosorption from multi ion solution systems several experimental studies have been reported up to now. Due to the relatively small amount of information on the interaction among non-ferrous metal 
ions during biosorption process on green algae biomass the effect of copper, zinc and nickel on their biosorption from multi ion solutions was experimentally studied in this work.

\section{Materials and methods}

\subsection{Biosorbent and model solutions preparation}

Chlorella kessleri, an unicellular green alga, obtained from the Institute of Botany of Slovak Academy of Sciences was used in this study. It was grown at $25^{\circ} \mathrm{C}$, aerated and lighted by $4 \times 40 \mathrm{~W}$ fluorescent tubes in liquid medium Milieu Bristol. The $\mathrm{pH}$ of the media was adjusted to 7.0 with $10 \% \mathrm{NaOH}$. In the Log phase of the growth, Chlorella kessleri cells were cooled, centrifuged at $3000 \mathrm{rpm}$ for $5 \mathrm{~min}$, washed twice in distilled water and then dried at $100^{\circ} \mathrm{C}$ for $3 \mathrm{~h}$. Algal cells in the form of powder were used as a biosorbent. Solutions of copper, zinc and nickel used for experiments were prepared by dissolving $\mathrm{CuSO}_{4} .5 \mathrm{H}_{2} \mathrm{O}, \mathrm{ZnSO}_{4} .7 \mathrm{H}_{2} \mathrm{O}$ and $\mathrm{NiSO}_{4} .7 \mathrm{H}_{2} \mathrm{O}$ in distilled water. Solutions $\mathrm{pH}$ was adjusted using $10 \% \mathrm{H}_{2} \mathrm{SO}_{4}$ and $10 \% \mathrm{NaOH}$.

\subsection{Metal biosorption experiments}

Powdered algae were used for the biosorption experiments at the concentration 2 $\mathrm{g} / \mathrm{l}$. Initial concentrations of copper, zinc and nickel in studied solutions ranged from 0 - $1000 \mathrm{mg} / \mathrm{l}$. Experiments were carried out according to the protocol for adsorption isotherms experiments (KADUKOVÁ and VIRČÍKOVÁ, 2003). The pH value of used solutions was 5.0. These solutions were agitated on a shaker during 24 hours. After this time solution samples were withdrawn for metal analysis. The concentration of metal ions was measured by atomic absorption spectroscopy (Varian AA20+).

The metal uptake $q$ was calculated from the mass balance equation as follows:

$$
q=\frac{V\left(C_{0}-C_{e}\right)}{m}
$$

where $q$ - the quantity of metal uptake by biomass $[\mathrm{mg} / \mathrm{g}], C_{0}$ - the initial metal concentration $[\mathrm{mg} / \mathrm{l}], C_{\mathrm{e}}$ - final (after sorption at equilibrium) metal concentration [mg/l], $V$ - the volume of solution [l] and $m$ - dry weight of the biomass added [g].

\subsection{Biosorption isotherm modeling}

The modeling of the biosorption process by using Chlorella kessleri was obtained by using different adsorption isotherms. In order to clarify the adsorption isotherms, Langmuir and Freundlich equations were chosen. The Langmuir equation can be expressed as:

$$
q_{e}=\frac{q_{\max } b C_{e}}{1+b C_{e}}
$$


where $q_{e}$ is the amount of metal ion sorbed on the biosorbent $(\mathrm{mg} / \mathrm{g})$ at equilibrium time, $q_{m}$ is monolayer capacity of the biosorbent $(\mathrm{mg} / \mathrm{g}), b$ is the biosorption constant $(1 / \mathrm{mg})$, and $C_{e}$ is equilibrium concentration of metal ion in solution $(\mathrm{mg} / \mathrm{l})$.

The Freundlich equation can be expressed as:

$$
q_{e}=K_{f} C_{e}^{1 / n}
$$

where $K_{f}$ and $n$ are empirical Freundlich constants and indicative of adsorption capacity and adsorption intensity, respectively, $q_{e}$ and $C_{e}$ are like the Langmuir equation described above. The value of $n$ is generally between 2 to 10. Langmuir mathematical model for binary system solutions can be expressed as:

$$
\begin{aligned}
& q_{1}=q_{\max 1} b_{1} C_{e 1} /\left(1+b_{1} C_{e 1}+b_{2} C_{e 2}\right) \\
& q_{2}=q_{\max 2} b_{2} C_{e 2} /\left(1+b_{1} C_{e 1}+b_{2} C_{e 2}\right)
\end{aligned}
$$

\section{Results and discussion}

\subsection{Influence of $\mathrm{Zn}^{2+}$ and $\mathrm{Ni}^{2+}$ on copper biosorption}

The influence of zinc and nickel on copper biosorption is shown in the Fig. 1. The presence of $\mathrm{Zn}$ had a positive effect on the copper biosorption, the biosorption capacity of copper increased two times in the solution $\mathrm{Cu}-\mathrm{Zn}$ in comparison with the biosorption capacity from the single copper solution.

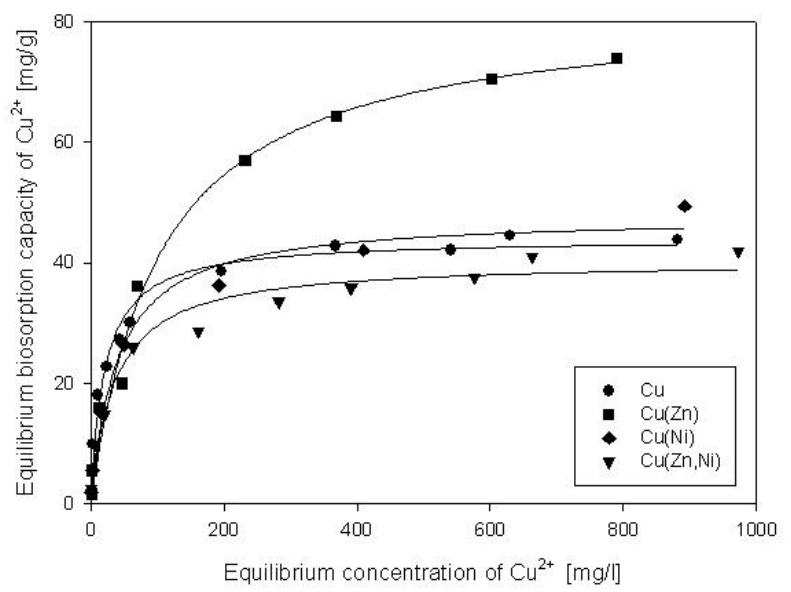

Fig. 1. Comparison of biosorption capacity of copper from one, two and three ion solutions using Langmuir model.

The positive effect of $\mathrm{Zn}$ on $\mathrm{Cu}$ biosorption was observed at higher equilibrium concentrations (above $70 \mathrm{mg} / \mathrm{l}$ ). It is possible that at higher concentrations copper is 
forced to bind to various types of binding sites resulting in the increase of the biosorption capacity. On the contrary Al-RUB et al. (2004) observed 10\% decrease of the copper biosorption capacity by alga Chlorella vulgaris in system $\mathrm{Cu}-\mathrm{Zn}$. Synergic effect was reported by TIEN (2002) during $\mathrm{Cu}^{2+}$ biosorption from the three-ion solution $\mathrm{Cu}-\mathrm{Cd}-\mathrm{Pb}$ by alga Eudorina elegans. The influence of nickel was negligible. In our case slight decrease of the biosorption capacity was observed for the three ion system $\mathrm{Cu}-\mathrm{Zn}-\mathrm{Ni}$.

\subsection{Influence of $\mathrm{Cu}^{2+}$ and $\mathrm{Ni}^{2+}$ on zinc biosorption}

Significant, almost double, increase of the biosorption capacity was also observed in the presence of copper during Zn biosorption (Fig. 2). Similarly as in the case of copper the increase was observed at higher equilibrium concentrations (above 290 $\mathrm{mg} / \mathrm{l}$ ). The influence of copper on zinc biosorption was negative at lower concentrations. The synergic effect of metal ions during biosorption is very rarely mentioned in literature so the detail explanation of that phenomenon is missing. Probably after the easily available binding sites are occupied the metal ions are forced to bind on less available sites which would not be occupied in more favorable situation. The presence of nickel or nickel and copper significantly decreased the zinc biosorption capacity. In this case metal ions are probably competing for binding sites (FAN et al., 2008).

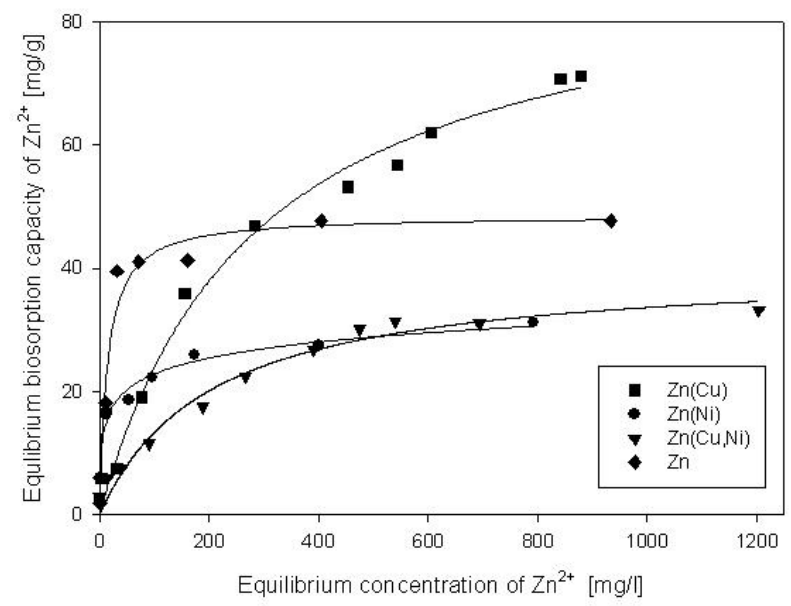

Fig. 2. Comparison of biosorption capacity of zinc from one, two and three ion solutions using Langmuir model.

Significant inhibition of zinc biosorption by copper presence was found when cork biomass was used as biosorbent (CHUBAR et al., 2004) as well as when the biomass of Fucus spiralis (ROMERA et al., 2008) or cyanobacteria Oscillatoria angustissima (MOHAPATRA and GUPTA, 2005) were used. Similarly PIPÍŠKA et al. (2010) found that $\mathrm{Zn}$ and $\mathrm{Cd}$ compete for the same binding sites on the Rhytidiadelphus 
squarrosus biomass surface resulting in equal biosorption efficiency. Negative effect on zinc biosorption was found also for other ions such as $\mathrm{Cd}^{2+}$ (REMENÁROVÁ et al., 2012).

\subsection{Influence of $\mathrm{Zn}^{2+}$ and $\mathrm{Cu}^{2+}$ on nickel biosorption}

The presence of copper had very positive effect also on the nickel biosorption (Fig. $3)$. Nickel biosorption capacity increased more than twice. Presence of zinc slightly increases the biosorption capacity of nickel in the range of low concentration. On the other hand in the highest concentration range the effect of zinc on nickel biosorption is negligible.

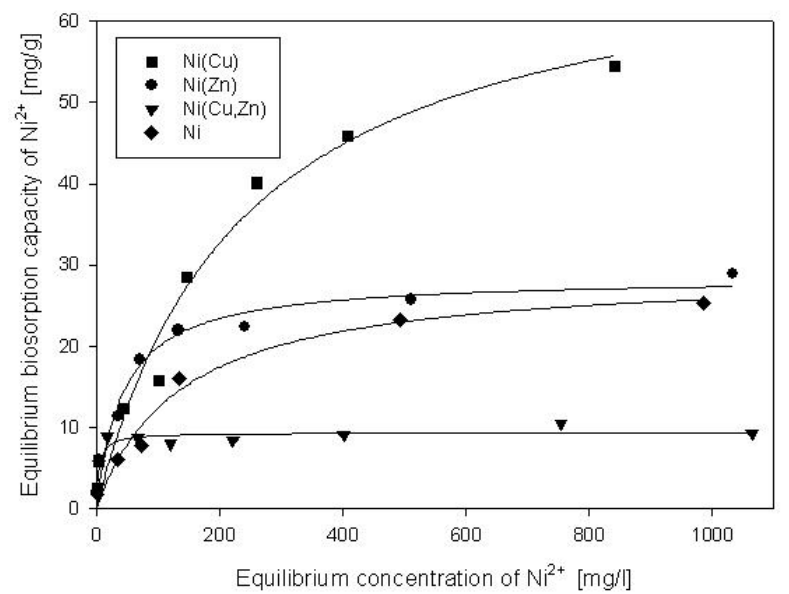

Fig. 3. Comparison of biosorption capacity of nickel from one, two and three ion solutions using Langmuir model.

Mutual influence of metals on their biosorption probably depends on the biosorbent type, too. VILLAESCUSA et al. (2004) observed negative effect of copper ( $20 \%$ decrease of the capacity) on nickel biosorption when grape waste was used as the biosorbent.

\subsection{Equilibrium modeling of process biosorption}

The highest value of maximum biosorption capacity from single ion solutions was found for zinc, which is consistent with experimental results. Based on the obtained experimental results the affinity constant $b_{L}$ was calculated using Langmuir mathematical model. The experimental results showed that zinc had the highest affinity for the green alga Chlorella kessleri. Using the Freundlich model similar results were obtained. Obviously algae had the highest adsorption capacity for zinc from single ion solutions.

Study of the biosorption from multiple ion solutions is much more complicated than from single ion solutions because it is always necessary to include the influence 
of other ions present in the solution. In the case of copper - zinc solution maximum biosorption capacity was higher for copper. On the other hand, in the solution containing zinc and nickel, the maximum biosorption capacity was higher for zinc.

The values of parameters calculated from the Langmuir model for single and multiple ion solutions are shown in Table 1 and 2.

Table 1. Model constants for single solution of metals.

\begin{tabular}{ccccc}
\hline Isotherms & Model constants & $\mathbf{C u}$ & $\mathbf{Z n}$ & $\mathbf{N i}$ \\
\hline \multirow{3}{*}{ Langmuir } & $\mathrm{q}_{\max }[\mathrm{mg} / \mathrm{g}]$ & 44.0 & $\mathbf{4 8 . 6}$ & 29.3 \\
& $\mathrm{~b}[1 / \mathrm{mg}]$ & 0.052 & 0.070 & 0.007 \\
& $\mathrm{R}^{2}$ & 0.976 & 0.971 & 0.921 \\
\hline \multirow{3}{*}{ Freundlich } & $\mathrm{K}_{\mathrm{f}}[1 / \mathrm{g}]$ & 10.1 & $\mathbf{1 2 . 9}$ & 2.21 \\
& $1 / \mathrm{n}$ & 0.230 & 0.213 & 0.363 \\
& $\mathrm{R}^{2}$ & 0.940 & 0.866 & 0.916 \\
\hline
\end{tabular}

Table 2. Model constants for binary system solutions.

\begin{tabular}{|c|c|c|c|c|c|}
\hline \multicolumn{2}{|c|}{ Langmuir } & $q_{\max }[\mathrm{mg} / \mathrm{g}]$ & $\mathbf{b}_{1}[\mathrm{l} / \mathrm{mg}]$ & $\mathbf{b}_{2}[\mathrm{l} / \mathrm{mg}]$ & $\overline{\mathbf{R}^{2}}$ \\
\hline \multirow{2}{*}{$\mathrm{Cu}+\mathrm{Zn}$} & $\mathrm{Cu}$ & 90.3 & 0.0007 & - & 0.9887 \\
\hline & $\mathrm{Zn}$ & 96.8 & - & 0.0036 & 0.9898 \\
\hline \multirow{2}{*}{$\mathrm{Cu}+\mathrm{Ni}$} & $\mathrm{Cu}$ & 57.3 & 0.0007 & - & 0.9951 \\
\hline & $\mathrm{Ni}$ & 62.7 & - & 0.0063 & 0.9849 \\
\hline \multirow{2}{*}{$\mathrm{Zn}+\mathrm{Ni}$} & $\mathrm{Zn}$ & 31.7 & -0.019 & - & 0.9959 \\
\hline & $\mathrm{Ni}$ & 28.5 & - & 0.0349 & 0.9785 \\
\hline
\end{tabular}

Maximum biosorption capacity for zinc from the system $\mathrm{Cu}-\mathrm{Zn}$ is slightly higher than that of copper. Zinc in $\mathrm{Zn}+\mathrm{Ni}$ system has a slightly higher biosorption capacity in comparison with nickel. In the $\mathrm{Cu}+\mathrm{Ni}$ solution system maximum biosorption capacities for studied metals were very similar. From the comparison of affinity constants for $\mathrm{Cu}+\mathrm{Zn}$ solution it is obvious that the algae have higher affinity to zinc. Surprisingly, algae have higher affinity to nickel in the other two studied systems.

As in the previous cases, in the study of the mutual influence of three ions - $\mathrm{Cu}^{2+}$, $\mathrm{Zn}^{2+}$ and $\mathrm{Ni}^{2+}-$ in multiple solution systems the adsorption isotherms was calculated. Biosorption capacity of studied metals decreased in the order: $\mathrm{Cu}>\mathrm{Zn}>\mathrm{Ni}$. At the present time well known mathematical models do not reliably calculate the necessary parameters. Therefore the modeling of three-and multi-ionic solutions still requires further study.

\section{Conclusions}

Wastewater treatment is very important issue of today because of the increase of pollutant amount released into surface water followed by the pollution of groundwater. Many studies are dedicated to the developing new wastewater treatment methods. Among the suitable methods biological methods represents good alternative for wastewater treatment. Copper, zinc and nickel present in the solution can influence their mutual biosorption significantly. Interestingly the presence of copper had positive 
effect on zinc and nickel biosorption capacity at higher equilibrium concentrations. Also zinc increased the biosorption capacity of copper. More study would be necessary to explain the phenomenon because in general metal ions should compete for binding sites on the biosorbent surface resulting in the decrease of the biosorption capacity. The decrease was observed only in some of two-ion solutions but in threeion solution the decrease of the biosorption capacity was reported for all three ions. Understanding of mutual influence of metals on their biosorption could significantly contribute to broader biosorption application in wastewater treatment.

Acknowledgement: Authors thanks to Ing. Vladimír Pencák for his help with the article preparation. This work was supported by VEGA 1/0235/12.

\section{References}

ABU AL-RUB, F.A., EL-NAAS, M.H., BENYAHIA, F., ASHOUR I.: Biosorption of nickel on blank alginate beads, free and immobilized algal cells. Process Biochem., 39, 2004, 1767-1773.

AKAR, T., ZERRIN, K.: Enhanced biosorption of nickel (II) ions by silica-gelimmobilized waste biomass: Biosorption characteristics in batch and dynamic flow mode. J. Hazard. Mater., 163, 2009, 1134-1141.

ANNA, W., ROMAN, G.: Biosorption of heavy metals from aqueous solutions onto peanut shell as a low-cost biosorbent. Desalination, 265, 2011, 126-134.

CHUBAR, N., CARVALHO, J.R., CORREIA M.J.N.: Cork biomass as biosorbent for $\mathrm{Cu}(\mathrm{II}), \mathrm{Zn}(\mathrm{II})$ and Ni(II). Colloid Surface Physicochem. Eng. Aspects 230, 2004, $57-65$.

CHUNPING, Y., MIN, L.: Biosorption of zinc(II) from aqueous solution by dried activated sludge. J. Environ. Sci., 22, 2010, 675-680.

FAN, H.J., YANG, H.S., TSAI, Y.S., FURUYA, E.: Prediction of individual Freundlich isotherms from binary and ternary phenolic compounds mixtures. Chemosphere 71, 2008, 886-893.

HORVÁTHOVÁ, H., KADUKOVÁ, J.: Effect of nickel on copper and zinc biosorption. Acta Metallurg. Slovaca, 14, 2008, 78-82.

KADUKOVÁ, J., VIRČÍKOVÁ, E.: Mineral Biotechnology III, Biosorption of metals from solution, $1^{\text {st }}$ Edition, VŠB-TU, Ostrava, 2003. ISBN 80-248-0244-9.

MAREŠOVÁ, J., PIPÍŠKA, M., ROZLOŽNÍK, M., HORNÍK, M., REMENÁROVÁ, L., AUGUSTÍN, J.: Cobalt and strontium sorption by moss biosorbent: Modeling of single and bingy metal systems. Desalination, 266, 2011, 134-141.

MOHAPATRA, H., GUPTA, R.: Concurrent sorption of $\mathrm{Zn}(\mathrm{II}), \mathrm{Cu}(\mathrm{II})$ and $\mathrm{Co}(\mathrm{II})$ by Oscillatoria angustissima as a function of $\mathrm{pH}$ in binary and ternary metal solutions. Bioresour. Technol., 96, 2005, 1387-1398.

PIPÍŠKA, M., HORNÍK, M., REMENÁROVÁ, L. AUGUSTÍN, J., LESNÝ, J: Biosorption of Cadmium, Cobalt and Zinc by Moss Rhytidiadelphus squarrosus in the Single and Binary Component Systems. Acta Chim. Slov., 57, 2010, 163-172.

REMENÁROVÁ, 1., PIPÍŠKA, M., HORNÍK, M., ROZLOŽNÍK, M., AUGUSTÍN, J., LESNÝ, J.: Biosorption of cadmium and zinc by activated sludge from single 
and binary solutions: Mechanism, equilibrium and experimental design study, J. Taiwan Inst. Chem. Eng., 43, 2012, 433-443.

ROMERA, E., GONZÁLEZ, F., BALLESTER, F., A., BLÁZQUEZ, M.L., MUOZ, J.A.: Biosorption of heavy metals by Fucus spiralis. Bioresour. Technol., 99, 2008, 4684-4693.

SAG, Y., ARDA, Y.: Mono and multi-component biosorption of heavy metal ions on Rhizopus arrhizus in a CFST. Process Biochem., 35, 2000, 787-799.

TIEN, C.J.: Biosorption of metal ions by freshwater algae with different surface characteristics. Process Biochem., 38, 2002, 605-613.

VILLAESCUSA, I., FIOL, N., MARTINEZ, M., MIRALLES, N. et al.: Removal of copper and nickel ions from aqueous solutions by grape stalks wastes. Water Res., 38, 2004, 992-10.

WANG, X., YONG, Q.: Equilibrium sorption isotherms for $\mathrm{Cu}^{2+}$ on rice bran. Process Biochem., 40, 2005, 677-680.

WEI - CHEN, K., CHIEH - CHEN, H.: Biosorption of nickel, chromium and zinc by MerP- expressing recombinant Escherichia coli. J. Hazard. Mater., 158, 2008, 100 $-106$.

Presented at the 2nd International Conference "Biotechnology and Metals - 2011", September 22-23, 2011, Košice, Slovak Republic. 